\title{
Role of the medical auxiliary in the control of sexually transmitted disease in a developing country
}

\author{
O. P. ARYA* AND F. J. BENNETT + \\ From the ${ }^{\star}$ Liverpool Royal Infirmary and the + University of Dar-es-Salaam, Tanzania
}

\begin{abstract}
Summary
Venereal diseases are becoming a major health problem in many developing countries where the greater part of primary medical care is undertaken by medical auxiliaries. Under these circumstances, the medical auxiliary has an important role to play in the control of these diseases but he can only do this with adequate training, support, and supervision from the professional doctors and specialists. In this paper, the role of the medical auxiliary is outlined and a case is also made for a speciallytrained cadre for venereal disease work in busy urban clinics in developing countries.
\end{abstract}

\section{Introduction}

Developing countries are facing more than their share of sickness with scarce resources including a lack of doctors, finance, equipment, and other facilities. Another important feature determining the pattern of health care in these countries is that a large majority of the population lives in rural areas. The doctor: population ratio may range from $1: 4,000$ in cities to over $1: 100,000$ in rural areas. There is little prospect of any significant changes in either

Presented at the 28th General Assembly of the IUVDT, Malta, April, 1975

Address for reprints: O. P. Arya, Consultant Venereologist, Liverpool Area Health Authority (Teaching), Liverpool Royal Infirmary, Pembroke Place, Liverpool L3 5PU, England

$\ddagger$ Present address of Dr F. J. Bennett, University of Nairobi, Kenya the doctor:population ratio in rural areas or the available finances. With these constraints and other associated problems such as communication and transport, most developing nations now provide a health service to a large part of the population by means of peripheral units (Table I) staffed by medical auxiliaries who, in most places, act as the only available 'professional' workers. An auxiliary is defined as 'a technical worker in a certain field with less than the full professional qualifications' (WHO, 1961). These medical auxiliaries thus cater for a large part of the population, up to $80-90$ per cent. in some countries. The need for the auxiliaries, especially in rural areas, is even greater because of the reluctance of the qualified professional staff to work in areas with poor amenities. The British Medical fournal (1974) has recently drawn attention to this problem. The philosophy, the principles, and related aspects of the subject of auxiliaries in health care were described by Fendall (1972).

\section{Incidence of sexually transmitted diseases}

While accurate figures are hard to obtain, there is evidence that all forms of venereal disease are very common in urban and rural areas of several developing countries: e.g. Kenya (Verhagen and Gemert, 1972); Uganda (Arya, 1973); Nigeria (Osoba and Onifade, 1973; Osoba, 1974); Rwanda (Meheus, de Clercq, and Prat, 1974); Bangladesh (Morton, 1974) and other countries (Király and Causse, 1974). Experience in Kenya (Verhagen, van der Ham, Heimans,

TABLE I Outline of the organization of health services in a developing country

\begin{tabular}{|c|c|}
\hline & $\begin{array}{l}\text { MINISTRY OF HEALTH (Senior Administrative Staff) } \\
\text { NATIONAL REFERENCE HOSPITAL (specialist services, research and laboratory facilities) } \\
\text { REGIONAL HOSPITAL (some specialist services and some laboratory facilities) } \\
\text { DISTRICT HOSPITAL (probably no specialist and minimal laboratory facilities) }\end{array}$ \\
\hline TB/Leprosy Clinic & 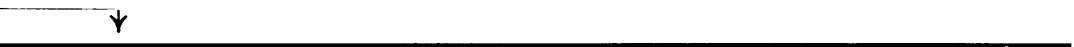 \\
\hline $\begin{array}{l}\text { Catering for } 80 \text { to } 90 \text { per cent. of } \\
\text { rural population }\end{array}$ & $\begin{array}{l}\text { RURAL HEALTH CENTRE (variable doctor supervision and routine microscopy) } \\
\text { DISPENSARY (limited staff and often no laboratory) } \\
\text { VILLAGE AID POST (visiting teams providing Maternity and Child Health and/or curative service) }\end{array}$ \\
\hline
\end{tabular}


Kranendonk, and Maina, 1971), Uganda (Arya and Bennett, 1974), and Zambia (Nwokolo, Hira, and Patel, 1974) shows that these diseases are being mismanaged to such an extent that there may now exist more problems than would have arisen if no treatment had been given. Very high rates of gonococcal strains less sensitive to penicillin and other antibiotics have been reported from Uganda (Arya and Phillips, 1970), Kenya (Verhagen and others, 1971), Bombay (Moses, Desai, Bhosle, and Trasi, 1971), Ethiopia (Plorde, Kidan, and Wright, 1973), and Thailand (Panikabutra and Suvanamalik, 1973) Table II. The situation in these countries and possibly elsewhere in Africa and the Far East is much worse than in Europe (Willcox, 1972).

The fear of the spread of venereal syphilis after mass campaigns against the endemic treponematoses and the consequent loss of cross-immunity from yaws (Guthe and Idsøe, 1968) is already becoming a reality in some developing countries. An epidemic of primary and secondary syphilis has been reported in Papua New Guinea (Rhodes and Anderson, 1970) and similar observations have been made in parts of Africa (Király and Causse, 1974). Very high syphilis rates in some parts of Uganda (Lomholt and Nsibambi, 1972; Arya, Ongom, and Tomusange, 1974; Arya and Taber, 1974), Upper Volta (RetelLaurentin, 1973), and the Central African Republic (Retel-Laurentin, 1974) suggest similar trends. Coupled with the socio-economic changes now taking place in the developing world, these trends pose a potentially serious threat of national and international spread of venereal syphilis. The epidemiological situation has been reviewèd by Idsoe, Király, and Causse (1973) and Causse (1974).

Some of the so-called 'minor' diseases, such as chancroid, granuloma inguinale, and lymphogranuloma venereum, which are very rare in the developed countries, are quite common in the developing countries. Chancroid is quite frequently found in Uganda (Lomholt and Nsibambi, 1972; Arya and others, 1974) and other parts of Africa (Willcox, 1958), granuloma inguinale in Papua New Guinea (Maddocks, 1967; Hart 1974) and parts of India
(Lal and Nicholas, 1970), and lymphogranuloma venereum in Thailand (Király and Causse, 1974) and parts of West Africa (Osoba, 1975).

In many developing countries, venereal diseases are often seen late in the natural history of the condition when complications have set in and the medical auxiliary is called on to treat not merely an irritating symptom but a serious complication or an emergency.

\section{Control}

\section{Rural areas}

Peripheral units in most developing countries are now considered to be the ideal units, offering an integrated service comprising all basic health care Lutwama, 1971) i.e. medical care, communicable disease control, maternal and child health services, environmental sanitation, public health nursing and home visiting, health education, and statistics. Such health centres are also suitable for urban communities.

These health centres are staffed with trained medical auxiliaries, preferably indigenous to the area concerned. Many countries, however, are not able to provide in every unit the full team of auxiliaries required to run all the basic health services so that only 'Health Centres' may offer the full spectrum and smaller units known as 'Dispensaries' may be limited to offering primary medical care for the sick and not all the preventive services. Dispensaries may be run by a less well-trained cadre of medical auxiliaries supervised from the Health Centre or District Hospital. Where the full range of basic health services are offered there is considerable opportunity for team work.

The workers responsible for health education, communicable disease control, home visiting, and maternal and child health obviously have overlapping roles in venereal disease control. In many developing countries some of the main categories would be Medical Assistant, Health Visitor, Enrolled Nurse and Midwife, Health Assistant, and Microscopist. These and other related terms have been defined in

TABLE I I Penicillin sensitivity of gonococci in various countries

\begin{tabular}{|c|c|c|c|c|c|}
\hline \multirow[b]{2}{*}{ Country } & \multirow[b]{2}{*}{ Authors } & \multirow[b]{2}{*}{ Date } & \multicolumn{3}{|c|}{ Percentage $M I C(\mu g . / m l)}$. \\
\hline & & & 0.05 or less & $0.06-0.12$ & $\begin{array}{l}\text { More than } 0.12 \text { (more than } \\
0.5 \text { in parenthesis) }\end{array}$ \\
\hline Uganda & Arya and Phillips & 1970 & $19 \cdot 1$ & $7 \cdot 5$ & $73.4 \quad(-)$ \\
\hline Kenya & Verhagen and others & 1971 & $34 \cdot 9$ & $4 \cdot 5$ & $60 \cdot 6 \quad(34 \cdot 7)$ \\
\hline Ethiopia & Plorde and others & 1973 & $50 \cdot 0$ & $29 \cdot 0$ & $21 \cdot 0 \quad(15 \cdot 8)$ \\
\hline Thailand & Panikabutra and Suvanamalik & 1973 & $23 \cdot 0$ & $10 \cdot 4$ & $66 \cdot 6 \quad(17 \cdot 7)$ \\
\hline Bombay (India) & Moses and others & 1971 & $44 \cdot 0$ & $(0.05-0.12)$ & $56 \cdot 0 \quad(20 \cdot 9)$ \\
\hline
\end{tabular}


a WHO Report (1961). A medical auxiliary is almost always the head of this health team. While all the auxiliaries have an important part to play in the venereal disease control programme, this paper will attempt to highlight the role of the key man in the team; the report is based on the authors' experiences in Uganda where this auxiliary is called a Medical Assistant.

In East Africa the Medical Assistant, after 4 years secondary education, has had 3 years training in nursing, basic medical instruction in diagnosis and management, and the public health aspects of various common disorders. All this training is geared to the local conditions. His responsibilities, in a country very short of doctors, are reflected in a wide range of functions. These functions include diagnosis and treatment of all common diseases (especially communicable diseases) and nutritional disorders; ability to recognize and refer difficult cases to the hospital; supervision of the work of other team members; continuation of the training of his staff; health education; liaison with other departments of the area; record keeping; and administration, including ordering drugs and working out daily rosters and clinics. In other words, he is both the 'general practitioner' and the 'public health officer' of the area served by the health centre.

The community aspect of his role can be seen in the integration of venereal disease control into other health programmes. A good medical assistant will include venereal disease as a subject in the health education programme conducted by all members of the staff. It will then be discussed in secondary school health programmes, in the antenatal sessions of mobile village maternity clinics and in child health clinics. He will ensure that 'satellite dispensaries' are providing adequate treatment and contact tracing when possible. In some areas with high incidence and prevalence a 'venereal disease control programme' may be introduced where the medical assistant can review all cases each month at a team meeting. Usually, however, venereal disease will be managed as just one group of communicable diseases amongst many, but requiring more emphasis on health education, early diagnosis, and adequate treatment and contact tracing based on good record keeping.

A recent study in a rural Health Centre in Uganda (Table III) showed very high rates of various venereal diseases among men and women (Arya and others, 1974). It also revealed some other important observations, such as a high default rate amounting to almost 50 per cent. of patients failing to return to complete the course of treatment for syphilis because they failed to appreciate the seriousness of the disease, or because of transport problems or other ill-defined reasons. The pattern shown in Table III, with the exception of lymphogranuloma venereum, is essentially similar to that observed by Willcox at a clinic in Accra, Ghana, nearly 30 years ago (Willcox, 1958).

Very high prevalence rates $(13.8$ per cent. for gonorrhoea) have been found in another rural area (Arya, Nsanzumuhire, and Taber, 1973), where many men had thickened epididymes and many women were sterile (Arya and Taber, 1975).

\section{Urban areas}

In big cities, the medical care in most developing countries is provided by Government Hospitals, Urban Health Centres run by the City Councils, and private practitioners. The contribution of private practitioners to community venereal disease control is sometimes questionable and does not come within the scope of this paper. Venereal disease clinics form part of the outpatient departments in big hospitals and Urban Health Centres. Most of these clinics in developing countries, as in the case of the Rural Health Centres, are run by Medical Assistants but with much more supervision and easier referral to qualified doctors. However, the quality of this service may also be rather poor. The incidence of

TABLE III Pattern of sexually transmitted diseases Kasangati Rural Health Centre (Uganda), 1972

\begin{tabular}{|c|c|c|c|c|c|c|}
\hline \multirow{2}{*}{\multicolumn{2}{|c|}{ Disease }} & \multicolumn{3}{|c|}{ No. of Diagnoses } & \multirow{2}{*}{$\begin{array}{l}\text { Kasangati } \\
(\text { Per cent., 1972) }\end{array}$} & \multirow{2}{*}{$\begin{array}{l}\text { Accra } \\
\text { (Per cent., 1944) } \\
\text { (Willcox, 1958) }\end{array}$} \\
\hline & & $\begin{array}{l}\text { Defined area } \\
\text { (Pop: } 12,000)\end{array}$ & $\begin{array}{l}\text { Outside } \\
\text { defined area }\end{array}$ & Total & & \\
\hline \multicolumn{2}{|c|}{ Gonorrhoea } & $264^{3}$ & 47 & 311 & $52 \cdot 9$ & $50 \cdot 7$ \\
\hline Syphilis & $\begin{array}{l}\text { Early infections } \\
\text { Latent }\end{array}$ & $\begin{array}{l}27 \\
19\end{array}$ & $\begin{array}{c}15^{b} \\
7\end{array}$ & $\begin{array}{l}42 \\
26\end{array}$ & $\begin{array}{l}7 \cdot 2 \\
4 \cdot 4\end{array}$ & $4 \cdot 2$ \\
\hline \multicolumn{2}{|c|}{ Chancroid } & 59 & 5 & 64 & $10 \cdot 9$ & $18 \cdot 2$ \\
\hline \multicolumn{2}{|c|}{ Lymphogranuloma Venereum } & 7 & 2 & 9 & $1 \cdot 5$ & $13 \cdot 7$ \\
\hline \multicolumn{2}{|l|}{ Other } & 105 & 31 & 136 & $23 \cdot 1$ & $13 \cdot 2$ \\
\hline \multicolumn{2}{|l|}{ Total } & 481 & 107 & 588 & $100 \cdot 0$ & $100 \cdot 0$ \\
\hline
\end{tabular}

ancludes 4 cases of ophthalmia neonatorum.

b includes 1 case of congenital syphilis. 
venereal disease in some of these cities is appallingly high (Verhagen and Gemert, 1972; Arya, 1973; Hopcraft, Verhagen, Ngigi, and Haga, 1973). Table IV compares figures for the whole of England with the Mulago Hospital VD clinic in the Ugandan capital, Kampala, (population approximately 350,000 ) where 18,000 cases of gonorrhoea, 2,000 cases of early infectious syphilis, 1,000 cases of chancroid, and 32 cases of congenital syphilis were diagnosed in 1971 (Lomholt and Nsibambi, 1972). In an estimated 3,000 cases darkfield examination was required. A problem of this size needs no further elaboration. However, perhaps as many, or more, cases were also seen and treated at other clinics run by the City Council and private practitioners. Table $\mathrm{V}$ compares four cities of developing and developed countries and shows that gonorrhoea and syphilis rates in Nairobi (Kenya) and Kampala (Uganda) were several times higher than in London (England) or Atlanta (USA). Reports from elsewhere show similar trends: Lagos-Nigeria (Daramola and Oyediran, 1971), Dakar-Senegal (Faye, 1972); Ibadan-Nigeria (Osoba, 1972); and LusakaZambia (Nwokolo and others, 1974).

TABLE IV Number of gonorrhoea, syphilis, and chancroid cases in one Ugandan clinic compared with the whole of England, 1971

\begin{tabular}{lll}
\hline & $\begin{array}{l}\text { Kampala (Uganda) } \\
\text { (Population }\end{array}$ & $\begin{array}{l}\text { Whole of England } \\
\text { (Population }\end{array}$ \\
& $\begin{array}{l}\text { approx. 350,000) } \\
\text { V.D. Clinic }\end{array}$ & approx. 46 million) \\
& Mulago Hospital & \\
\cline { 2 - 3 } & 18,000 & \\
\hline Gonorrhoea & 2,000 & 55,988 \\
Early syphilis & 32 & 1,606 \\
Early congenital syphilis & 1,000 & 16 \\
Chancroid & & 55 \\
\hline
\end{tabular}

TABLE V Gonorrhoea and infectious syphilis case rates per 100,000 population of four large cities of Uganda, Kenya, United Kingdom, and United States of America, 1971

\begin{tabular}{|c|c|c|}
\hline \multirow[b]{2}{*}{ City } & \multicolumn{2}{|c|}{ Case rates per 100,000 population } \\
\hline & Gonorrhoea & $\begin{array}{l}\text { Primary and } \\
\text { secondary syphilis }\end{array}$ \\
\hline $\begin{array}{l}\text { Kampala (Uganda) } \\
\text { V.D. Clinic, Mulago } \\
\text { Minimum total estimated }\end{array}$ & $\begin{array}{r}5,143 \\
10,000\end{array}$ & $\begin{array}{r}572 \\
1,000\end{array}$ \\
\hline $\begin{array}{l}\text { Nairobi (Kenya) } \\
\text { V.D. Clinic } \\
\text { Minimum total estimated }\end{array}$ & $\begin{array}{l}3,600 \\
7,000\end{array}$ & $\begin{array}{l}280 \\
500\end{array}$ \\
\hline Greater London $(\mathrm{UK})^{\mathbf{a}}$ & $308 \cdot 03$ & $8 \cdot 48$ \\
\hline Atlanta, Georgia (USA)b & 2,510 & $87 \cdot 6$ \\
\hline
\end{tabular}

a Department of Health and Social Security, London

bAmerican Social Health Association (1972) 'Today's V.D. Control Problem'. New York
One of the chief reasons for this high prevalence of venereal diseases in the poorer countries is inadequate treatment, improper treatment, or no treatment at all. Lack of medicines, observed by Faye (1972) in Senegal, is a familiar difficulty in many developing countries, especially in the peripheral units, but that is only a part of the explanation. A recent survey in several rural and urban Health Centres (Arya and Bennett, 1974) showed that almost all the patients alleged to have gonorrhoea were being diagnosed by intuition, and receiving repeated injections of small doses of P.A.M. (procaine penicillin in oil with aluminium monostearate). This schedule, besides being expensive in terms of time and money, was causing more harm than good by selecting and spreading the less sensitive strains of the gonococcus (Arya and Bosa, 1973). The concept of an effective treatment of gonorrhoea with a single dose of penicillin in appropriate form and dosage was either not known or not understood. Virtually no attempt was made at contact tracing either through shortage of staff or through lack of appreciation of the consequences. There is thus an urgent need for cheap, effective safe, simple, and standardized treatment schedules, to cope with the problem in these areas: for instance, single-dose schedules for gonorrhoea, preferably effective for incubating syphilis as well, and longacting preparations for the treatment of syphilis and chancroid. This would help not only the patients but also the Health Centre staff who are pressed for time, especially in clinics where a good proportion of the attendance may be made up of patients coming for repeated treatment. In this connection, the 'rule of thumb' regimes advocated by Willcox (1951) a quarter of a century ago would be equally appropriate now.

\section{Training the Medical Auxiliary}

Clearly, there is considerable scope to improve the situation within the existing framework in many developing countries. This raises the question of training programmes orientated towards certain tasks. It might also include organizing venereal disease clinics, depending on the demand. The educational objectives for the Medical Auxiliary as regards venereal disease control should include essential history taking, examination of the patient (male, female, and child), diagnosis and treatment of common sexually transmitted diseases, recognition of difficult, serious, or unusual conditions to be referred to the hospital, record keeping, use of the microscopist, follow-up, contact tracing, analysis of the local distribution and determinants of disease, and the prevention and control of venereal disease including health education. Knowledge of the local socio-cultural factors which largely determine traditional sexual mores is vital to the control of these 
diseases. Studies in developing countries (Bennett, 1962; Ongom, Lwanga, Mugisha, and Mafigiri, 1971; Verhagen and Gemert, 1972; Arya and others, 1973; Hart, 1974) show that the patterns differ from those in the western nations and may even vary from one area to another within a country. The medical auxiliary will understand these problems more easily if he is indigenous to the area concerned. Most of this information is already included in the communicable disease part of the training programme but may need up-dating and appropriate emphasis. More important, is intensive training in the venereal disease clinic at the teaching hospital which should have complete facilities. (Without this nucleus of facilities in the national and teaching hospitals there can be no real progress in control in any country). Initial training can be supplemented by in-service or refresher training provided periodically by the supervising or visiting doctor. The latter refresher course could take the form of group teaching and could include Medical Assistant, Midwife, Health Assistant, and possibly other members of the staff. All of them have important roles, such as the screening for syphilis in the antenatal clinics by the Midwife and the tracing of contacts and defaulters by the Health Assistant.

In larger cities, where venereal diseases are very common, there is scope for full-time venereal diseases auxiliaries, that is Medical Assistants with specialized training including the use of the darkground microscope. These workers are capable of managing most common uncomplicated cases if the methods involved are routine and straightforward. Auxiliaries specializing in other fields, such as orthopaedics and anaesthesia, have been successfully trained in Uganda (King, 1966).

The administration of such training programmes is the responsibility of the appropriate authority (e.g. the Principal Medical Officer in Charge of Training) in the Ministry of Health, usually with collaboration from the medical schools (e.g. the Departments of Community Medicine and of Dermato-Venereology). Training should always be realistic and include practical work in a clinic. Where training schools are situated in urban areas then field work should include work in a rural health centre and thus the training school must have links with the city and district health administration.

\section{Conclusion}

The concept of a venereal disease auxiliary is in keeping with the principles of rational medicine (Barlovatz, 1970). Many developing countries cannot afford to employ more than a handful of venereologists or specialists in the allied fields. Some countries, in fact, have none. The overall scarcity of fully-qualified professional workers in these countries means that tasks which are the strict prerogative of doctors and specialists in the developed countries must be delegated to auxiliaries, who are, in fact, already tackling the various health programmes in developing countries. If equipped with better knowledge and skills, their contribution to venereal disease control can be improved. It is not suggested that all medical auxiliaries should undergo specialized training, but where it is needed, that is where the sexually transmitted diseases are most common and the daily number of patients very great, as in urban areas, this extra training is desirable. This realistic approach is perhaps the only choice, if the situation is not to get worse before it gets better.

\section{References}

ARYA, O. P. (1973) Brit. F. vener. Dis., 49, 134

- and BENNETT, F. J. (1974) The use and misuse of medicines in some sexually transmitted diseases in Uganda. Proceedings of the 1973 Annual Scientific Conference of the East African Medical Research Council, 'The Use and Abuse of Drugs and Chemicals in Tropical Africa', ed. A. F. Bagshawe and others, pp. 79-86. East African Literature Bureau, Nairobi and Bosa, C. B. (1973) Brit. F. vener. Dis., 49, 460

- , NsANZumuhire, H., and TABER, S. R. (1973) Bull. Wld Hlth Org., 49, 587

, Ongom, V. L., and Tomusange, E. T. (1974) E. Afr. med. F., 51, 109

and PhILlips, I. (1970) Brit. F. vener. Dis., 46, 149

- and TABER, S. R. (1974) 'Some observations on venereal disease and infertility in the Teso District of Uganda' in Report of an International Workshop on Correlates of Sub-fertility and Infertility in Africa, held at Ibadan, Nigeria, 1973, pp. 78-80

- (1975) 'Correlates of Venereal Disease and Fertility in Rural Uganda'. WHO/VDT/RES 75.339

Barlovatz, A. (1970) 'Principles of Rational Medicine'. Wright, Bristol

BeNNETT, F. J. (1962) E. Afr. med. F., 39, 332

British Medical fournal (1974) 'Brain Drain-the Pattern Changes', 4, 674 (Leader)

Causse, G. (1974) 'Epidemiology of the Sexually Transmitted Diseases in Tropical Regions-Need for a Better Approach'. WHO/VDT, 74, 396

Daramola, T., and Oyediran, M. A. (1971) Israel f. med. Sci., 7, 288

FaYe, A. (1972) Postgrad. med. F., 48 (Suppl. 1), p. 43

Fendall, N. R. E. (1972) 'Auxiliaries in Health Care'. Johns Hopkins Press, Baltimore

GutHe, T., and IDSøE, O. (1968) Brit. f. vener. Dis., 44, 35

HART, G. (1974) Ibid., 50, 453

Hopcraft, M., Verhagen, A. R., Ngigi, S., and Haga, A. C. A. (1973) Bull. Wld Hlth Org., 48, 581

Idsøe, O., KirAly, K., and CaUsSe, G. (1973) Wld Hlth Org. Chron., 27, 410

KING, M. (ed.) (1966) 'Medical Care in Developing Countries', pp. 7:5. Oxford University Press, Nairobi

KIRÁLY, K., and CAUSSE, G. (1974) 'A worldwide view' in 'Today's V.D. Control Problem, pp. 47-53. American Social Health Association, New York 
Lal, S., and Nicholas, C. (1970) Brit. F. vener. Dis., 46, 461

Lomнolt, G., and Nsibambi, J. (1972) Uganda med. F., 1, 109

Lutwama, J. S. W. (1971) Afro Technical Papers No. 3. W.H.O., Brazzaville

Maddocks, I. (1967) Papua New Guinea med. F., 10, 49

Meheus, A., Clerce, A. DE, and Prat, R. (1974) Brit. $\mathcal{F}$. vener. Dis., 50, 50

MORTON, R. S. (1974) Ibid., 50, 64

Moses, J. M., Desai, M. S., Bhosle, C. B., and Trasi, M. S. (1971) Ibid., 47, 273

Nwokolo, U., Hira, P. R., and Patel, J. M. (1974) E. Afr. med. F., 51, 331

Ongom, V. L., Lwanga, V. N., Mugisha, J. K., and MAFIGIRI, J. T. (1971) Ibid., 48, 367

Osoba, A. O. (1972) Brit. F. vener. Dis., 48, 116 (1974) 'The role of sexually transmitted diseases in infertility among Nigerians' in 'Sub-fertility and Infertility in Africa', Report of an International Workshop on Correlates of Sub-fertility and Infertility in Africa, held at Ibadan, Nigeria, 1973, pp. 81-84 (1975) Personal communication

- and ONIFADE, O. (1973) W. Afr. med. f., 22, 23

Panikabutra, K., and Suvanamalik, S. (1973) Brit. $\mathcal{F}$. vener. Dis., 49, 209
Plorde, J. J., Kidan, T. G., and Wright, L. J. (1973) Ibid., 49, 260

Retel-Laurentin, A. (1973) 'Population, 28', pp. 793815

(1974) 'Sub-fertility in Black Africa-the case of the Nzaraka in Central African Republic' in 'Subfertility and Infertility in Africa'. Report of an International Workshop on Correlates of Sub-fertility and Infertility in Africa, held at Ibadan, Nigeria, 1973, pp. $69-75$

Rhodes, F. A., and Anderson, S. E. J. (1970) Papua and New Guinea med. F., 13, 49

Verhagen, A. R., and Gemert, W. (1972) Brit. F. vener. Dis., 48, 277

- Van Der Ham, M., Heimans, A. L., Kranendonk, O., and Maina, A. N. (1971) Bull. Wld Hlth Org., 45, 707

Willcox, R. R. (1951) E. Afr. med. F., 28, 483

- (1958) Centr. Afr. F. Med., 4, 432 (1972) Brit. F. vener. Dis., 48, 163

World HEalth Organization (1961) 'The Use and Training of Auxiliary Personnel in Medicine, Nursing, Midwifery, and Sanitation.' W.H.O. Tech. Rep. Ser., No. 212, Geneva 